\title{
Development Of Augmented Reality Application As A Mathematics Learning Media In Elementary School Geometry Materials
}

\author{
Ni Putu Dinayusadewi \\ Fakultas Ilmu Pendidikan, Universitas Pendidikan Ganesha, Singaraja, Indonesia \\ email:dinayusa7@gmail.com
}

Gusti Ngurah Sastra Agustika

Fakultas Ilmu Pendidikan, Universitas Pendidikan Ganesha, Singaraja, Indonesia email: gn.sastra.a@undiksha.ac.id

\section{A R T I C L E I N F O \\ Article history: \\ 1 Maret 2020 Received in revised form \\ 30 Maret 2020 \\ Accepted 11 April 2020 \\ Available online 15 \\ Mei 2020 \\ Kata Kunci: \\ matematika, media \\ pembelajaran, Augmented \\ Reality}

\section{Keywords:}

mathematics, learning

media, Augmented Reality

\begin{abstract}
A B S T R A K
Permasalahan pada penelitian ini adalah kurangnya media pembelajaran interaktif pada materi geometri Sekolah Dasar yang membuat siswa kesulitan memahami penjelasan yang disampaikan guru. Tujuan penelitian ini adalah untuk merancang dan menghasilkan aplikasi media pembelajaran matematika pada materi geometri bangun ruang khusnya kubus dan balok berbasis teknologi Augmented Reality untuk siswa kelas V SD, serta mengetahui tingkat kelayakan produk dari subyek uji coba dan validator. Tahap pengembangan media pembelajaran ini terdiri dari lima tahapan yaitu Analysis, Design, Development, Implementation, dan Evaluation. Untuk metode pengumpulan data digunakan metode observasi langsung dan angket tertutup. Angket hasil penelitian dianalisis dengan menggunkan analisa penilaian skala likert sehingga diperoleh hasil sebagai berikut: Hasil uji coba terhadap validator ahli materi dengan persentase skor $92,50 \%$ yang termasuk kategori sangat baik dengan keterangan sangat layak. Validator ahli desain media dengan persentase skor $93,00 \%$ yang termasuk kategori sangat baik dengan keterangan sangat layak. Respon penggunaan produk dari tiga orang guru SD dengan persentase skor $89,33 \%$ yang termasuk kategori sangat baik. Respon penggunaan produk dari lima belas orang siswa SD dengan persentase skor $83,73 \%$ dengan kategori sangat baik.Disimpulkan bahwa aplikasi media pembelajaran
\end{abstract} matematika SD pada materi geometri berbasis teknologi Augmented Reality yang telah dikembangkan dapat digunakan di sekolah dasar sebagai media pembelajaran matematika.

\begin{abstract}
A B S T R A C T
The problem of this research is the lack of interactive learning media on elementary school geometry which makes it difficult for students to understand the explanation that conveyed by the teacher. This research aims to design geometrical mathematics learning media especially cubes and blocks based on Augmented Reality technology for fifth-grade elementary school students and to know the level of product worthiness from the subject and validator. The development process of this research consists of five steps like Analysis, Design, Development, Implementation, and Evaluation. The data collection method used was a closed questionnaire. The results of the research questionnaire were analyzed using a Likert scale analysis, so the following results are obtained: The results trial of the material expert validator showed a percentage of 92.50\% which is included in the excellent category with very decent information. Media design expert validator with a percentage of $93.00 \%$ which is included in the excellent category with very decent information. Product response of three elementary school teachers with a percentage score of $89.33 \%$ included in the very good category. Product responses of fifteen elementary school students with a percentage score of $83.73 \%$ with a very good category. It was concluded that the application of elementary geometrical mathematics learning media based on Augmented Reality technology can be used in elementary schools as a medium for learning mathematics.
\end{abstract}

\section{Introduction}

The utilization of technology and its development in the world of education is increasingly advancing and developing, so it requires a lot of updates to compensate for these developments (Husaini, 2014). But in reality in the world of education, technological developments that are increasingly advanced can not be fully used optimally (Sawitri, Sumiati, \& Fitriani, 2019). Problems such as teacher's inability to use IT facilities that are not utilized properly are one of the factors that hinder the development of technology in the world of education, especially in Indonesia (Sahelatua, 2017). However, if utilized properly, technology in the world of education can facilitate the learning process and can optimize student achievement (Soimah, 2018). As stated by (Personal, 2017), learning media in the form of IT was developed to be able to convey information and knowledge to many people more easily. Curriculum 2013 also requires each teacher to balance conventional 
learning with IT-based media, in addition to facilitating the process of teaching and learning indirectly it can also rely on students on technology early on (Sri, 2010). By knowing all the advantages of using IT-based learning media in the world of education it is felt necessary to apply this IT media in various teaching and learning activities in schools.

The application of IT in schools is not only done on certain subjects but should be used for all subjects. In subjects that are often considered difficult by students such as mathematics (Siregar, 2017), the use of IT-based media will be very useful for conveying material to students because although mathematics is often considered difficult, the value of mathematics is one of the determinants of whether or not a person can students continue their education to higher fields (Suandito, 2017). The general perception of students in mathematics is to consider it a difficult subject, so by using a fun IT-based media such as an interactive application that presents images and sounds will make students more interested in learning. In elementary schools IT-based media for mathematics subjects is still lacking, this is known from the results of observations made at various elementary schools in Denpasar and Badung. Moreover, for building materials, the learning media provided by the school are teaching aids which are mostly made of cardboard and plastic. Based on the results of interviews conducted randomly on the fifth-grade students who get the material to build space, it is known that the teaching aids have not been able to make them fully understand the material that is delivered by the teacher. The reason is that the number of learning media is limited and the size is too small so it is difficult for students in the back to see the teacher's explanation in front of the class.

Problems with this learning media should be minimized with other learning media. Because there are still learning media that can be used to deliver space building materials such as interactive videos, power-point slides, interactive learning applications, and many others (Nasaruddin, 2018). One interactive learning application that can be used to teach space building material is Augmented Reality (AR). Augmented Reality is a technology that can display virtual objects in a real environment with the help of a smartphone (Azuma, 2010). By using this technology, geometry objects are transformed into virtual objects and then through a smartphone displayed on a real object. In geometry material, Augmented Reality is used to visualize geometric objects with the hope to make it easier for students to understand each element of these geometric shapes such as line segments, vertices, fields, sides, and so forth. (Suharso, 2012) in his research said that learning using Augmented Reality technology will facilitate teachers in teaching and make students more interested in learning. This is because Augmented Reality technology has a high level of interactivity so that it can interact with its users.

This good interactivity is utilized by developers in creating various Augmented Reality based learning media. Some of the Augmented Reality-based learning media include teaching material on traditional house examples (Pramono, 2013) and human organs (Santoso, 2013). As for some of the advantages of using Augmented Reality in this broad learning is being able to introduce students to technology in the field of education, supporting the 2013 curriculum policy which requires the use of IT in learning and supporting government efforts in developing superior human resources towards the golden generation of Indonesia in 2045 and ready to face the era of the industrial revolution 4.0 which in principle makes IT technology the basis for its development. With all these advantages, using Augmented Reality is considered very appropriate to teach students to know technology early on. This is also supported by the results of previous research by (Mareta, 2015) and (Huda, Bagus, \& et al, 2018) which states that Augmented Reality is appropriate for use in learning in schools because of its high level of interactivity.

Because it has a high level of interactivity, to be able to create an Augmented Reality-based learning media an understanding of the design of application development is needed. (Azuma, 2010) in his article explained that Augmented Reality technology is included in the category of Virtual Reality. In Virtual Reality, the environment is artificial and human as if it were in a virtual world, whereas in Augmented Reality the environment is made real but with the addition of artificial virtual objects. According to (Olwal, 2010) explained that before making an Augmented Reality, three important components must be prepared, first is the scene generator which is software that is useful for ending the modeling of virtual objects displayed. The second component is a tracking system, useful for detecting markers / real world views that are useful as a foothold or where virtual objects are displayed. The last component is the smartphone that is used to display Augmented Reality.

In addition to these three important components, to be able to make a good Augmented Reality also requires a display system. Display systems aim to display virtual objects created, in this context geometric objects. By using this technology, it takes a computer to add virtual objects and display the results to users, besides that it also requires a camera to get a picture of the surrounding environment. Mobile devices are increasingly developing, making display systems techniques sophisticated. Almost all smartphones have been equipped with cameras so it is very appropriate to apply Augmented Reality technology. As stated, (Komang Candra, 2018) in his research that the better a smartphone camera will make the appearance of the resulting Augmented Reality have clearer visual quality. But to produce a good Augmented Reality, in addition to a smartphone also requires a PC to process and add 3D objects. The combination of these two technologies makes 
the appearance of an Augmented Reality more qualified (Judge, Development of Learning Media Based on Augmented Reality, 2018).

In addition to these devices, a marker is also needed, a marker is a real object that is used as a foothold by 3D objects when displayed by a Smartphone camera. Markers are made in the form of symbols such as barcodes printed on paper or other objects to facilitate the detection process by the camera (Apriyani, 2016), so the camera on the smartphone will detect the marker and then display the 3D object when the Augmented Reality application is run. Objects that are used as markers are generally in the form of black and white barcodes of various shapes which are then scanned by a smartphone camera so that they can visualize virtual objects. The condition that an object can be used as a marker is that it must be supported by the Software Development Kit (SDK), so the software used to develop (in this study use 3D unity software) there must be an AR SDK, and in this study, the Vuforia SDK is used. By using Vuforia, a marker is registered online on the official Vuforia website. To find out how well a marker can visualize virtual objects, there are provisions before creating a marker. One easy way is to pay attention to the number of edges of a marker design, the more edges, the better the marker is in displaying 3D objects (Priono, 2014).

By knowing the advantages of using Augmented Reality in the world of education, it is in line with the purpose of this research, namely to develop elementary mathematics learning media on geometry material, especially cubes and blocks based on Augmented Reality applications for fifth-grade students of elementary schools. This research was conducted because generally the application of Augmented Reality is used to teach historical material, natural sciences, and other subjects, but there has never been any research related to the use of Augmented Reality as a learning media application especially for geometry materials of cubes and beams.

\section{Method}

This type of research is development research whose purpose is to produce a product, the development procedure consists of five stages, namely (1) Analysis, (2) Design (3) Development, (4) Implementation/execution, and (5) Evaluation/feedback (Personal, 2017). The reason for using this model is because it has a clear and systematic development sequence so that it facilitates the development process.

The initial process of this research begins by analyzing needs through observation and interviews, by doing this information will be more easily obtained so that the output created can be more useful and targeted. Next is designing the application design that will be made such as flowcharts and application storyboards, the aim is to facilitate the application so that it is more structured. The third step is the creation of an application, at this stage, all designs that have been prepared previously are executed until they become a product that is ready for use. At this stage includes making the application interface design, 3D object creation, marker design, building applications using Unity, testing the marker to making a questionnaire that will be used when testing applications on the subject and validator. After this process is completed, the next step is to implement the application on the subject: 3 elementary school teachers and 15 fifth grade students at Mengwi No.1 Elementary School. But before it can be implemented on the subject, the application is first tested on a validator, the aim is to find out how feasible the application is made and to know the deficiencies of the product so that it can be fixed first before it can later be tested on the subject. The validator in this study is the material expert validator and the learning media design expert validator. While the tools used to collect research data from test subjects and validators are closed questionnaires, questionnaires are made with the eligibility criteria of application-based learning media that adapt previous relevant research including the suitability of material content, language, graphic design, color, ease and interactivity (Fujiastuti, 2018). The validity test for this questionnaire was carried out with the expert judgment test, so the expert judges will assess the questionnaire made related to its eligibility as a measurement tool in this research development. After the questionnaire is ready, the questionnaire is given to the research validator. Furthermore, by using a Likert scale assessment analysis, the scores obtained from each validator are analyzed to determine the appropriateness of the application made.

Table 1. Analysis of Likert Scale Assessment

\begin{tabular}{cc}
\hline Score & Information \\
\hline 5 & Strongly agree \\
4 & Agree \\
3 & Not agree \\
2 & Disagree \\
1 & Strongly disagree \\
\hline
\end{tabular}

(Source: Arikunto, 2015: 284 with researcher modification) 
After the data obtained from the validator is analyzed using a Likert scale assessment, a percentage score will be obtained from each of the validators. Furthermore, to be able to make decisions regarding the feasibility of the application using the following decision-making criteria:

Tabel 2. Indicators of Questionnaire Score Decision

\begin{tabular}{ccc}
\hline $\begin{array}{c}\text { Level of } \\
\text { Achievement (\%) }\end{array}$ & Qualification & Information \\
\hline $81-100 \%$ & Very good & Very decent / very valid \\
$61-80 \%$ & Well & Eligible / valid \\
$41-60 \%$ & Pretty good & Inadequate / less valid \\
$21-40 \%$ & Not good & Ineligible / invalid \\
$<20 \%$ & Very Poor & Very improper / very invalid \\
\hline
\end{tabular}

(Arikunto, 2015: 244 with researcher modification)

When the percentage of the validator questionnaire scores met the good qualifications, the product was tested on teachers and students at SD Mengwi No.1 to determine the response of using the application in learning. For calculating scores and decision making from the teacher and student questionnaires the same data analysis techniques were used as used in the research validator questionnaire. The final step of this research is the evaluation phase, the aim is to review the products related to the previous implementation to maximize the final product of this research. This stage is done by looking at the comments given by the validator and the test subjects in the comment's column in the questionnaire. So that it known whether or not the application requires improvement and can be fixed immediately to improve the quality of the output of this development.

\section{Result and Discussion}

This development research product in the form of Augmented Reality based mathematics learning media applications that can be used to teach cube and block geometry material to fifth-grade elementary school students. This learning media application was developed to create an IT-based interactive learning media for mathematics, especially for cubes and blocks. After the application passes the validity test from the validator of the material expert, the validator of the media design expert, the teacher and the fifth-grade students of the elementary school, the following are the results of the validity test of each validator and the subjects of this research trial:

Table 3. Application Feasibility Test Results

\begin{tabular}{lcc}
\hline \multicolumn{1}{c}{ Respondent } & Percentage & Information \\
\hline Material Expert Validator & $92,50 \%$ & Very decent \\
Media Design Expert Validator & $93,00 \%$ & Very decent \\
Elementary School teacher & $89,33 \%$ & Very decent \\
Elementary Class V students & $83,73 \%$ & Very decent \\
\hline
\end{tabular}

The development of mathematics learning media applications on material based on Augmented Reality technology was developed through five stages, starting from the Analysis, Design, Development, Implementation, and Evaluation stages. All stages were carried out following the research design that had been previously designed, and product validation by the validator and the test subjects, namely the teacher and students, were carried out at the implementation stage by using a measuring instrument in the form of a closed questionnaire that had been previously validated by the expert judgment to determine the eligibility of the questionnaire as measuring instruments (Sugiyono, 2017). The validation of the application to the material expert validator includes the material suitability criteria, the design of the material in the application and language, as said (Fujiastuti, 2018) in his research on the media eligibility criteria, that the material eligibility criteria for the application include several things including content suitability, material design, and language. So, by using a questionnaire that includes these criteria, the application is validated by the material expert. And based on the results of the validation of the application of two material experts who were assessed using a questionnaire, scattered on a score of 5 (very good) and 4 (good). So, from the aspect of the contents of the material included in the criteria very well with a percentage of $92.50 \%$ score and is feasible to be applied in 
primary schools as a learning medium. The material in this application consists of geometry material taken from elementary school math class V students of 2013 revised 2017 curriculum. The design of the material is made colorful, this is in line with research conducted by (Sujarwo, 2017) which states that the colors that exist in the media teaching will attract students to know something.

The results of the subsequent validation are by the instructional media design expert, as well as the validation is done to the material expert, then the validation by the media design expert is carried out using a questionnaire that adapts the feasibility criteria of IT-based media previously done by (Fujiastuti, 2018). For media design experts the eligibility criteria include the appearance of graphic design, color, interactivity, and ease of operation. And based on the results of the validation of two media design experts, it was found that most of the validator ratings of the application design aspects were spread at a score of 5 (very good) and 4 (good). From the aspect of media design, this application is included in very good criteria with a percentage score of $93.00 \%$. The interface design or interface of this application is made in full color to make it look attractive, but without forgetting the value of the writing function of each material is made easy for the user to read. There is also a "guide" feature that can make it easier for users to operate applications, this is relevant to research conducted by (Setianingrum, 2017) which states that ease of operation of applications is important in developing IT-based media. In addition to these features, there are the main features in this application that is the Augmented Reality feature, there is this feature the user will be presented with 3-dimensional objects of geometric shapes associated with the material, such as cubes, beams, nets to illustrations to illustrate the volume of building space. As stated by (Lestari, 2019) in his research that with the Augmented Reality feature, application design becomes more interesting and varied to teach mathematics to elementary school students.

Next is the results of the validation carried out on three elementary school teachers, validation is done by using a questionnaire that adapts the eligibility criteria of IT-based media (Fujiastuti, 2018). Based on the results of trials on three teachers who were assessed using a questionnaire with aspects of the assessment that included the contents of the material, product design, and function of the application, the assessment results were spread on a score of 5 (very good) and 4 (good). Seeing the results of this assessment, learning media in the form of this application received a good response from elementary school teachers with a percentage score of $89.33 \%$ which is included in an excellent qualification with very decent information. This shows that the teacher's response to the developed application is good and the application can be used as a learning medium. The final validation result is the validation done on fifteen fifth grade elementary school students at SD Mengwi No.1, the aim is not only to get product validation from small groups but also to get a response to the use of the product. This is done based on previous research by (Hidayat Baron, 2015) which states that product use response is needed when developing a product, especially for new products that have not been tried by students. Just as before, to get responses to the use of applications from students using a questionnaire with several aspects of assessment such as ease of use of the product, application design, and material content (Fujiastuti, 2018). Based on questionnaire data obtained from students, the assessment scores varied with a range of scores between 5 (very good), 4 (good), 3 (sufficient), and 2 (less). Based on the results of this assessment, a percentage score of $83.73 \%$ which is included in a very good qualification with very decent information. Based on these results, it can be seen that students' responses to the developed application are good and the application is feasible to be applied in elementary schools as a means to support learning, especially mathematics.

Referring to the results of data analysis obtained in this study of validators and test subjects, it was concluded that the application of elementary mathematics learning media on geometry material based on Augmented Reality technology is feasible to be used as a learning medium with very good qualifications. This research is also relevant to previous research conducted by (Sahahaman, 2013) and (Hamzah, 2019) regarding the design of applications based on Augmented Reality technology.

\section{Conclusion}

Based on data analysis the results of this study can be concluded as follows: (1) The development process includes five stages, namely the Analyst (Analysis), Design / Design (Development), Development (Development), Implementation/execution (Implementation), and Evaluation/feedback (Evaluation), this research model was adapted from (Personal, 2017) and previous research by (Sokheh, 2017) who used a similar model. (2) Augmented Reality application developed is valid/feasible to be used as a medium of learning mathematics in elementary schools with the results of data analysis from the validator and the test subjects as follows: (a) the material expert validator states the application is very feasible with a percentage score of 
$92.50 \%$, (b) the validator of the media design expert said the application was very feasible with a percentage score of 93.00 , (c) three elementary school teachers stated the application was very feasible with a percentage score of $89.33 \%$, (d) fifteen elementary students stated the application was very feasible with the percentage score of $83.73 \%$. The decision making criteria in this study were adapted from (Arikunto, 2015). Based on the percentage of the results of the study, it can be concluded that the application of elementary mathematics learning media on geometry material based on Augmented Reality technology that has been developed can be used in elementary schools as a learning medium. So with the end of this research, it is suggested that elementary school teachers should be able to use IT-based media more often if possible to arouse students' enthusiasm in learning. And students should take advantage of various learning media today that can educate even outside the school environment such as the application developed in this study. And the last suggestion addressed to researchers and other developers, should be able to increase the development of IT-based media that is more qualified both in terms of design and content of the material to increase the variety of media in student learning at school.

\section{References}

Apriyani, M. E. (2016). Analisis Penggunaan Marker Tracking Pada Augmented Reality Huruf Hijaiyah. JURNAL INFOTEL - Informatika Telekomunikasi Elektronika, 8(1), 71.

Arikunto, S. (2015). Dasar- Dasar Evaluasi Pendidikan. Jakarta: Bumi Aksara.

Azuma, R. T. (2010). A Survey of Augmented Reality. Malibu: Hughes Research Laboratories.

Fujiastuti, A. (2018). Pengembangan media pembelajaran retorika berbasis ARCS dengan aplikasi flash. prosiding $S A G A, 16-24$.

Hakim, L. (2018). Pengembangan Media Pembelajaran Pai Berbasis Augmented Reality. Lentera Pendidikan : Jurnal Ilmu Tarbiyah dan Keguruan, 21(1), 59-72.

Hakim, L. (2018). Pengembangan Media Pembelajaran Pai Berbasis Augmented Reality. Lentera Pendidikan : Jurnal Ilmu Tarbiyah dan Keguruan, 21(1), 59-72.

Hamzah, S. (2019). Pengembangan Media Pembelajaran Perangkat Keras Jaringan Berbasis Augmented Reality Pada Platform Android. Vokasional Teknik Elektronika dan Informatika (VOTEKNIKA), 7(3), 1-12.

Hidayat Baron, I. F. (2015). Implementasi independent t-test pada aplikasi pembelajaran multimedia ragam dan gerak seni tari daerah kalimatan selatan. Kumpulan Jurnal Ilmu Komputer (KLIK), 2(1), 11-21.

Huda, K., Bagus, \& dkk. (2018). Pengembangan Media Pembelajaran Berbasis Android Menggunakan Augmented Reality Pada Materi Bangun Ruang Sisi Datar. Jurnal Pendidikan Matematika dan Sains, 6(01), 61-69.

Husaini, M. (2014). Pemanfaatan Teknologi Informasi Dalam Bidang Pendidikan (E-Education). Jurnal Mikrotik, 2(1), 1-5.

Komang Candra, A. H. (2018). Pengembangan Aplikasi Mobile Augmented Reality untuk Mendukung Pengenalan Koleksi Museum. Jurnal Teknologi Informasi dan Ilmu Komputer, 5(3), 347.

Lestari, N. S. (2019). Penggunaan Variasi Media Pembelajaran untuk Meningkatkan Motivasi dan Minat Belajar Matematika Siswa Kelas XI IPS 3 SMA Negeri 2 Merauke. Musamus Journal of Mathematics Education, 1(2), 74-79.

Mareta, A. (2015). Implementasi Media Ajar Bangun Ruang Berbasis Augmented Reality Pada SMPN 2 Selomerto Kabupaten Wonosobo. Semarang: Jurusan Teknik Elektro, Universitas Negeri Semarang.

Nasaruddin. (2018). Media Dan Alat Peraga Dalam Pembelajaran Matematika. Al-Khwarizmi: Jurnal Pendidikan Matematika dan Ilmu Pengetahuan Alam, 3(2), 21-30.

Olwal, A. (2010). An Introduction to Augmented Reality. Sweden: KTH Royal Institute of Technology.

Pramono, A. (2013). Media Pendukung Pembelajaran Rumah Adat Indonesia Menggunakan Augmented Reality. $11(1), 122$.

Pribadi, B. (2017). Media \& Teknologi dalam Pembelajaran. Jakarta: Kencana.

Priono, T. Y. (2014). Analisis Pengaruh Perbedaan Market Terhadap Display System. 1-16.

Sahelatua, L. S. (2017). Kendala Guru Memanfaatkan Media It Dalam Pembelajaran Di Sdn 1 Pagar Air Aceh Besar. Journal of Chemical Information and Modeling, 53(9), 1689-1699. 
Sahertian, J. (2013). Pengembangan Media Pembelajaran Berbasis Teknologi Augmented Reality Pada Pokok Bahasan Sel. Jurnal Teknologi Elektro dan Kejuruan, 19(1), 9-14.

Santoso, A. (2013). Rancang Bangun Aplikasi Pembelajaran Organ Tubuh Berbasis Augmented Reality. 8.

Sawitri, E., Sumiati, M., \& Fitriani, Y. (2019). Hambatan Dan Tantangan Pembelajaran. Seminar Nasional Pendidikan Program Pascasarjana Universitas PGRI Palembang, 202-213.

Setianingrum, M. (2017). Penggunaan Variasi Media Ajar Terhadap 3 Gaya Belajar Siswa Dalam Pembelajaran Bahasa Jepang. JAPANEDU: Jurnal Pendidikan dan Pengajaran Bahasa Jepang, 2(1), 1.

Siregar, N. R. (2017). Persepsi Siswa Pada Pelajaran Matematika: Studi Pendahuluan Pada Siswa yang Menyenangi Game. Prosiding Temu Ilmiah X Ikatan Psikologi Perkembangan Indonesia, 224-232.

Soimah, I. (2018). Pengaruh Media Pembelajaran Berbasis Komputer Terhadap Hasil Belajar Ipa Ditinjau Dari Motivasi Belajar Siswa. Natural: Jurnal Ilmiah Pendidikan IPA, 5(1), 38.

Sokheh, M. S. (2017). Pengembangan Media Video Pembelajaran Dengan Model Addie Materi Passing Bola Basket. Pendidikan Jasmani, Kesehatan, dan Rekreasi, 8(2), 1-11.

Sri, S. D. (2010). Sebagai Dasar Pengenalan Teknologi Informasi Pada Guru Taman Kanak-Kanak Di Kota Semarang. Jurnal Abdimas, 14(2), 1-5.

Suandito, B. (2017). Bukti Informal Dalam Pembelajaran Matematika. Al-Jabar : Jurnal Pendidikan Matematika, 8(1), 13.

Suarjana, I. M. (2019). Pendidikan Matematika di Kelas Tinggi. Singaraja: Universitas Pendidikan Ganesha.

Sugiyono. (2017). Metode Penelitian Pendidikan (Pendekatan Kuantitatif, Kualitatif dan R\&D). Bandung: Alfabeta.

Suharso, A. (2012). Model Pembelajaran Interaktif Bangun Ruang 3d Berbasis Augmented Reality. 11(24), 10.

Sujarwo, S. O. (2017). Pengaruh Warna terhadap Shortterm Memory Pada Siswa Kelas VIII Smp N 37 Palembang. Jurnal Psikologi Islami, 3(1), 33-42. 